\title{
Expression pattern of NLRP3 and its related cytokines in the lung and brain of avian influenza virus $\mathrm{H} 9 \mathrm{~N} 2$ infected BALB/C mice
}

\author{
Meng $\mathrm{Yu}^{\dagger}$, Kaizhao Zhang ${ }^{\dagger}$, Wenbao Qi, Zhiqiang Huang, Jinhui Ye, Yongjiang Ma, Ming Liao \\ and Zhangyong Ning*
}

\begin{abstract}
Background: H9N2 avian influenza virus (AIV) becomes the focus for its ability of transmission to mammals and as a donor to provide internal genes to form the new epidemic lethal influenza viruses. Residue 627 in PB2 has been proven the virulence factor of H9N2 avian influenza virus in mice, but the detailed data for inflammation difference between H9N2 virus strains with site 627 mutation is still unclear. The inflammasome NLRP3 is recently reported as the cellular machinery responsible for activation of inflammatory processes and plays an important role during the development of inflammation caused by influenza virus infection.

Methods: In this study, we investigated the expression pattern of NLRP3 and its related cytokines of IL-1 $\beta$ and TNF-a in BALB/c mice infected by H9N2 AIV strains with only a site 627 difference at both mRNA and protein levels at different time points.

Results: The results showed that the expression level of NLRP3, IL-1 3 and TNF- $a$ changed in the lung and brain of

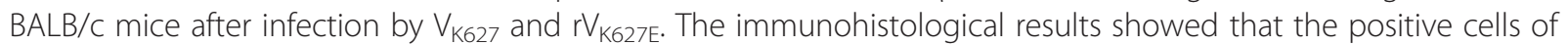
NLRP3, IL-1 $\beta$ and TNF- $a$ altered the positive levels of original cells in tissues and infiltrated inflammatory cells which caused by H9N2 infection.

Conclusions: Our results provided the basic data at differences in expression pattern of NLRP3 and its related cytokines in BALB/c mice infected by H9N2 influenza viruses with only a site 627 difference. This implied that NLRP3 inflammasome plays a role in host response to influenza virus infection and determines the outcome of clinical manifestation and pathological injury. This will explain the variable of pathological presentation in tissues and enhance research on inflammation process of the AIV H9N2 infection.
\end{abstract}

Keywords: Avian influenza virus, H9N2, BALB/c mice, NLRP3, IL-1 $\beta$, TNF- $a$

\section{Introduction}

H9N2 avian influenza viruses (AIV) are widely circulating in both wild birds and domestic poultry populations since isolated from turkeys in 1966 and become a pandemic threat to human [1-4]. Evidences showed that this subtype of avian influenza virus had been transmitted from birds to mammals such as dogs, cats and pigs [5-7]. Birds and infected mammals are thought to be the reassortment for forming new strains based on this

\footnotetext{
* Correspondence: mliao@scau.edu.cn; ningzhyong@scau.edu.cn ${ }^{\dagger}$ Equal contributors

College of Veterinary Medicine, South China Agricultural University, Guangzhou 510642, People's Republic of China
}

subtype AIVs [8,9]. H9N2 avian influenza virus caused low mortality and immunosuppression in chickens $[10,11]$ and become a more prevalent pathogen in human populations since the first infection case of human in 1998 [12,13]. It is noteworthy that it can provide the inner genes to other AIV types and form new lethal influenza viruses to humans, such as H5N1, H7N9 and H10N8 [14-18] and co-circulates with the other AIV types during their prevalence $[3,19]$. The inflammation process of H9N2 infection may be slight respiratory symptoms in human $[12,13]$, but the more serious clinical signs in mice [10,20-22]. Our previous reports showed that a single-amino-acid substitution in PB2 
residue 627 changed the virulence of H9N2 avian influenza virus in mice and showed different pathological change in lung and brain [21,22]. The relationship of pathological changes associated with the NLRP3 and its related cytokines production need to be explored.

Nod-like receptors (NLRs), one of pathogen-associated molecular patterns (PAMPs), play a significant role in inflammation development in virus infection and regulate the host response to adaptive immunity [23]. Among different types of inflammasome, the NLRP3 inflammasome is well characterized in a variety of mammalian cells which is mainly composed of the NLRP3, the adaptor protein apoptosis-associated speck-like protein (ASC) and caspase-1. NLRP3 is the central component of the NLRP3 inflammasome which can recruit procaspase-1 with ASC [24]. With the controlling of cytosolic multiprotein complexes inflammasome protease caspase- 1 has pivotal function in regulating the cleavage and maturation of pro-IL-1 $\beta$, which is the inactive precursor of IL-1 $\beta$, in response to a variety of agonists or stimuli [25]. IL-1 $\beta$ is an important cytokine with a broad range of biological activities. In influenza infection, IL-1 $\beta$ bind with its receptors leads to the activation of multiple cytokines, including TNF- $\alpha$ [26] which plays an important role in the early stages of host defense against influenza infection [27]. The expression pattern and histological distribution of NLRP3, IL- $1 \beta$ and TNF- $\alpha$ during the H9N2 avian influenza virus infection in mice are still unknown.

Here, we provided the basic data of expression pattern and histological distribution of NLRP3, IL-1 $\beta$ and TNF$\alpha$ in lung and brain during infection in BALB/c mice by H9N2 avian influenza virus strains with only a difference at site 627 in PB2. This will allow us to further understand the function of NLRP3 inflammasome for the role of residue 627 in PB2 in mammalian hosts. To our knowledge, there are very few papers to show the expression profile and histological distribution change of NLRP3, IL$1 \beta$ and TNF- $\alpha$ after H9N2 influenza virus infection.

\section{Results}

\section{Virulence of avian influenza virus H9N2 in mice}

The weight loss, clinical signs after inoculation with $V_{K 627}$ and $\mathrm{rV}_{\mathrm{K} 627 \mathrm{E}}$ avian influenza virus H9N2 in mice are consistent with our previous reports [21,22]. $V_{\mathrm{K} 627}$ virus induced significant viral encephalitis while $\mathrm{rV}_{\mathrm{K} 627 \mathrm{E}}$ not and $\mathrm{V}_{\mathrm{K} 627}$ virus induced mild interstitial pneumonia while $\mathrm{rV}_{\mathrm{K} 627 \mathrm{E}}$ only induced very slight lung change [21,22].

\section{Expression changes of NLRP3, IL-1 $\beta$ and TNF- $\alpha$ during H9N2 AIV infection}

The expression level of NLRP3, IL- $1 \beta$ and TNF- $\alpha$ analyzed by quantitative real-time PCR altered in the lung and brain of the infected mice and differed with the control (Figure 1).
In the lung, expression level of NLRP3 increased after infection compared with the control. In $\mathrm{V}_{\mathrm{K} 627}$ group, the expression level of NLRP3 was sharply achieved its highest level at $3 \mathrm{dpi}$ from the lowest at $1 \mathrm{dpi}$ before continuously declined at 5 and $6 \mathrm{dpi}$. In $\mathrm{rV}_{\mathrm{K} 627 \mathrm{E}}$ group, the expression level of NLRP3 was gently achieved its highest level at $5 \mathrm{dpi}$ from the lowest at $1 \mathrm{dpi}$. The expression level of NLRP3 in the control was significantly lower than $\mathrm{rV}_{\mathrm{K} 627 \mathrm{E}}$ and $\mathrm{V}_{\mathrm{K} 627}$ infection group $(\mathrm{P}<0.05)$ at 1 dpi. The expression level of NLRP3 in $V_{K 627}$ group is very significantly higher than that of $\mathrm{rV}_{\mathrm{K} 627 \mathrm{E}}$ group at 3, 5 and 6 dpi $(\mathrm{P}<0.01)$ (Figure 1A). Expression level of IL-1 $\beta$ in lungs of $V_{K 627}$ and $r V_{K 627 E}$ group were very significantly higher than the control $(\mathrm{P}<0.01)$. In $\mathrm{V}_{\mathrm{K} 627 \mathrm{E}}$ group, expression level of the IL- $1 \beta$ was lowest at $1 \mathrm{dpi}$ and then sharply increased to its peak at $3 \mathrm{dpi}$ before continuously declined at $5 \mathrm{dpi}$ and $6 \mathrm{dpi}$. In $\mathrm{rV}_{\mathrm{K} 627 \mathrm{E}}$ infection group, the expression level of IL- $1 \beta$ rose from 1 dpi to $5 \mathrm{dpi}$ which achieved its peak before declined to the lowest level at $6 \mathrm{dpi}$. The expression level of IL-1 $\beta$ in $V_{K 627}$ infection group was very significantly higher than $\mathrm{rV}_{\mathrm{K} 627 \mathrm{E}}$ group at 3,5 and $6 \mathrm{dpi}(\mathrm{P}<0.01)$ (Figure $\left.1 \mathrm{~B}\right)$. Expression level of TNF- $\alpha$ in the lung of $\mathrm{V}_{\mathrm{K} 627}$ and $\mathrm{rV}_{\mathrm{K} 627 \mathrm{E}}$ infection groups were very significantly higher than the control $(\mathrm{P}<0.01)$. In $\mathrm{V}_{\mathrm{K} 627 \mathrm{E}}$ group, the expression level of TNF- $\alpha$ achieved its peak at 3 dpi and then continuously declined to its lowest at $6 \mathrm{dpi}$. In $\mathrm{rV}_{\mathrm{K} 627 \mathrm{E}}$ group, the expression level of TNF- $\alpha$ rose from the lowest level at $1 \mathrm{dpi}$ to the highest level at $5 \mathrm{dpi}$ before declined at $6 \mathrm{dpi}$. At all time-points, the expression level of TNF- $\alpha$ in $V_{K 627}$ infection group was very significantly higher than $\mathrm{rV}_{\mathrm{K} 627 \mathrm{E}}$ infection group $(\mathrm{P}<0.01)$ (Figure 1C).

In the brain, expression level of NLRP3 rose after $\mathrm{V}_{\mathrm{K} 627}$ and $\mathrm{rV}_{\mathrm{K} 627 \mathrm{E}}$ infection compared with the control. The expression level of NLRP3 in $V_{K 627}$ infection group was higher than $\mathrm{rV}_{\mathrm{K} 627 \mathrm{E}}$ group and the control at $1 \mathrm{dpi}$ and then achieved its peak at 3 dpi before declined at 5 and $6 \mathrm{dpi}$. In $\mathrm{rV}_{\mathrm{K} 627 \mathrm{E}}$ infection group, the expression level of NLRP3 continuously increased till achieving its highest level at $5 \mathrm{dpi}$. The expression level of NLRP3 in $\mathrm{V}_{\mathrm{K} 627}$ infection group at $3 \mathrm{dpi}$ and in $\mathrm{rV}_{\mathrm{K} 627 \mathrm{E}}$ group at 5 dpi and 6 dpi were significantly higher than the control $(\mathrm{P}<0.05)$ (Figure 1D). Expression tendency of IL-1 $\beta$ in brain was similar to NLRP3 and the expression level in $\mathrm{V}_{\mathrm{K} 627}$ group is very significantly higher than the other two groups at all time-points except $1 \mathrm{dpi}$. The expression level of IL-1 $\beta$ in $\mathrm{rV}_{\mathrm{K} 627 \mathrm{E}}$ group was very significantly higher than control group at 5 dpi $(\mathrm{P}<0.05)$ (Figure 1E). Expression level of TNF- $\alpha$ in the control was very significantly lower than $\mathrm{V}_{\mathrm{K} 627}$ and $\mathrm{rV}_{\mathrm{K} 627 \mathrm{E}}$ infection group at all days detected $(\mathrm{P}<0.01)$. Expression level of TNF- $\alpha$ in $\mathrm{V}_{\mathrm{K} 627}$ group were very significantly higher than $\mathrm{rV}_{\mathrm{K} 627 \mathrm{E}}$ group at $3 \mathrm{dpi}$ and $5 \mathrm{dpi}(\mathrm{P}<0.01)$. Different with NLRP3 and IL-1 $\beta$, expression level of 


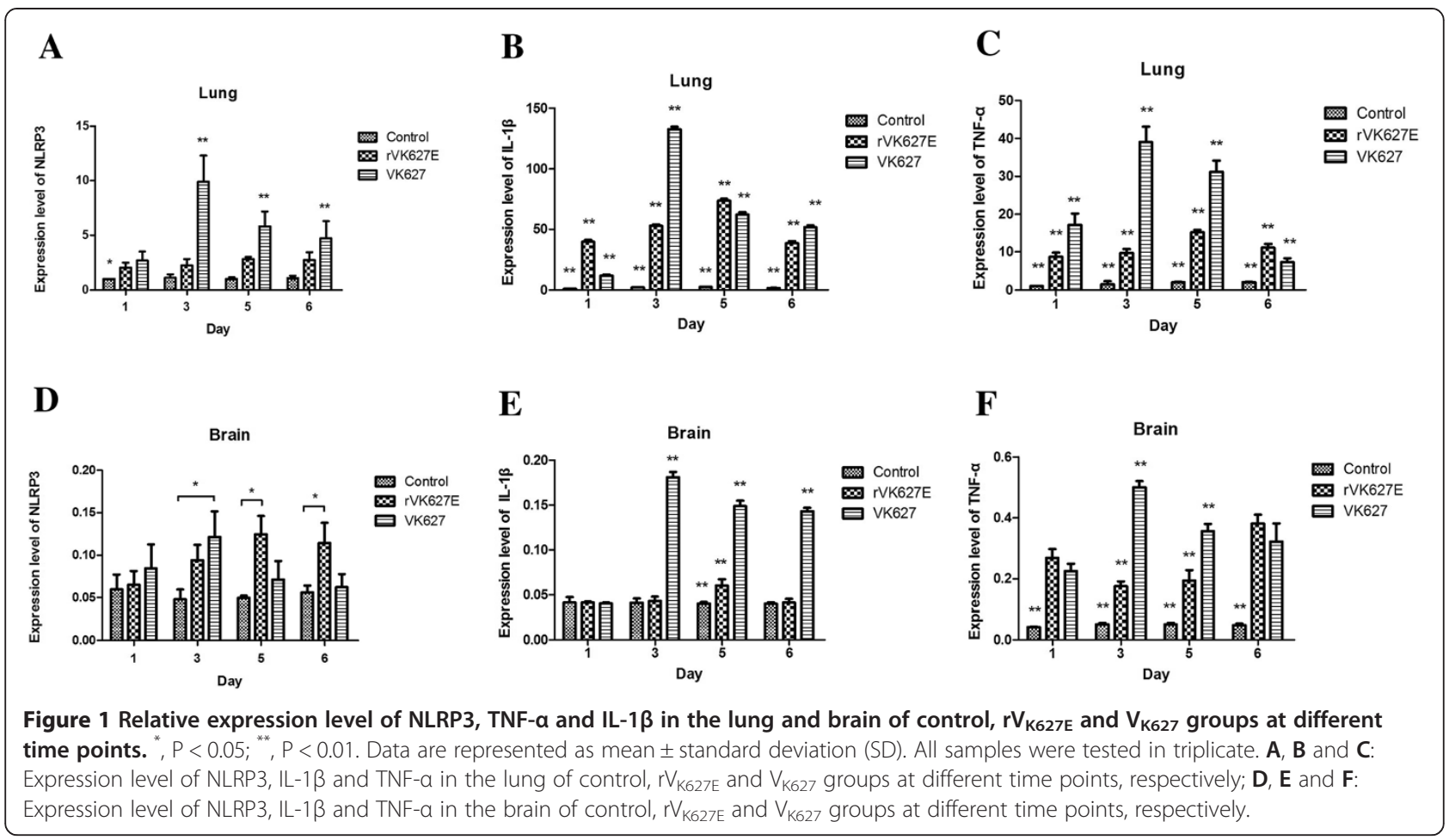

TNF- $\alpha$ in $\mathrm{rV}_{\mathrm{K} 627 \mathrm{E}}$ continually declined to its lowest level at $5 \mathrm{dpi}$ from $1 \mathrm{dpi}$ and then sharply rose to its highest level at $6 \mathrm{dpi}$. (Figure 1F).

Immunohistochemical detection of NLRP3, IL-1 $\beta$ and TNF- $\alpha$ Immunohistochemical detection was performed to show the cell and tissue specific distribution of the NLRP3, IL$1 \beta$ and TNF- $\alpha$ in the lung and brain. For the control, the positive cells and distribution of NLRP3 in lung and brain were consistent with our previous study [28] (Figure 2A). The infiltrated inflammatory cells and exudation were positive in the lung of infected groups (Figure $2 \mathrm{~B}$ and $\mathrm{C}$ ). In the cerebral cortex of brain, neurons showed medium positive staining in the control and $\mathrm{rV}_{\mathrm{K} 627 \mathrm{E}}$ group, while stronger positive staining was detected in $\mathrm{V}_{\mathrm{K} 627}$ group (Figure 2D, E and F).

IL- $1 \beta$ in the lung of the control showed some alveolar epithelial cells of the pulmonary alveoli and bronchiole were very weak positive (Figure 3A), while mild to strong positive of the same cells in $\mathrm{rV}_{\mathrm{K} 627 \mathrm{E}}$ and $\mathrm{V}_{\mathrm{K} 627}$ groups (Figure $3 \mathrm{~B}$ and $\mathrm{C}$ ). In the cerebral cortex of the brain, neurons showed negative staining and only punctiform positive in matrix in the control and $\mathrm{rV}_{\mathrm{K} 627 \mathrm{E}}$ group, (Figure $3 \mathrm{D}$ and $\mathrm{E}$ ), while strong positive staining in neuron cells with punctiform positive in matrix in $\mathrm{V}_{\mathrm{K} 627}$ infection group (Figure $3 \mathrm{~F}$ ).

In the lung, the TNF- $\alpha$ positive cells were mainly the epithelial cells of the pulmonary alveoli in mice of the control (Figure 4A), while stronger positives in the epithelial cells of the pulmonary alveoli as well as the epithelial cells and the submucosa of bronchi and bronchioles in both $\mathrm{V}_{\mathrm{K} 627}$ and $\mathrm{rV}_{\mathrm{K} 627 \mathrm{E}}$ infected mice (Figure 4B and C). Notably, the shed bronchial epithelial cells, intraluminal secretions and infiltration cells in the alveolar wall and around the bronchi and bronchioles are strong positives in the lung of infected groups (Figure 4B and C). In the brain, TNF- $\alpha$ were focal expression of matrix and there was no significant difference between infected groups and the control (Figure 4D, E and F).

\section{Discussion}

Mice are routine laboratory animals to characterize host responses during influenza virus infection [29] and different kinds of mice exhibit different susceptibilities and immune responses during infection [27]. Otte et al. reported that $\mathrm{BALB} / \mathrm{c}$ mice were more sensitive to $\mathrm{H} 5 \mathrm{~N} 1$ [30] which recombined from H9N2 $[17,18]$ than C57BL/ 6 mice. Our previous researches proved that H9N2 avian influenza virus strains with only single-amino-acid substitution in PB2 residue 627 had different pathogenicity in BALB/C mice $[21,22]$. The relationship between this pathogenesis change and inflammation active factor NLRP3 is still obscure. As the lung and brain showed significant differences in these two H9N2 avian influenza virus strains infection, we chosen to detect the expression patterns of NLRP3 and its related cytokines of IL$1 \beta$ and TNF- $\alpha$. 


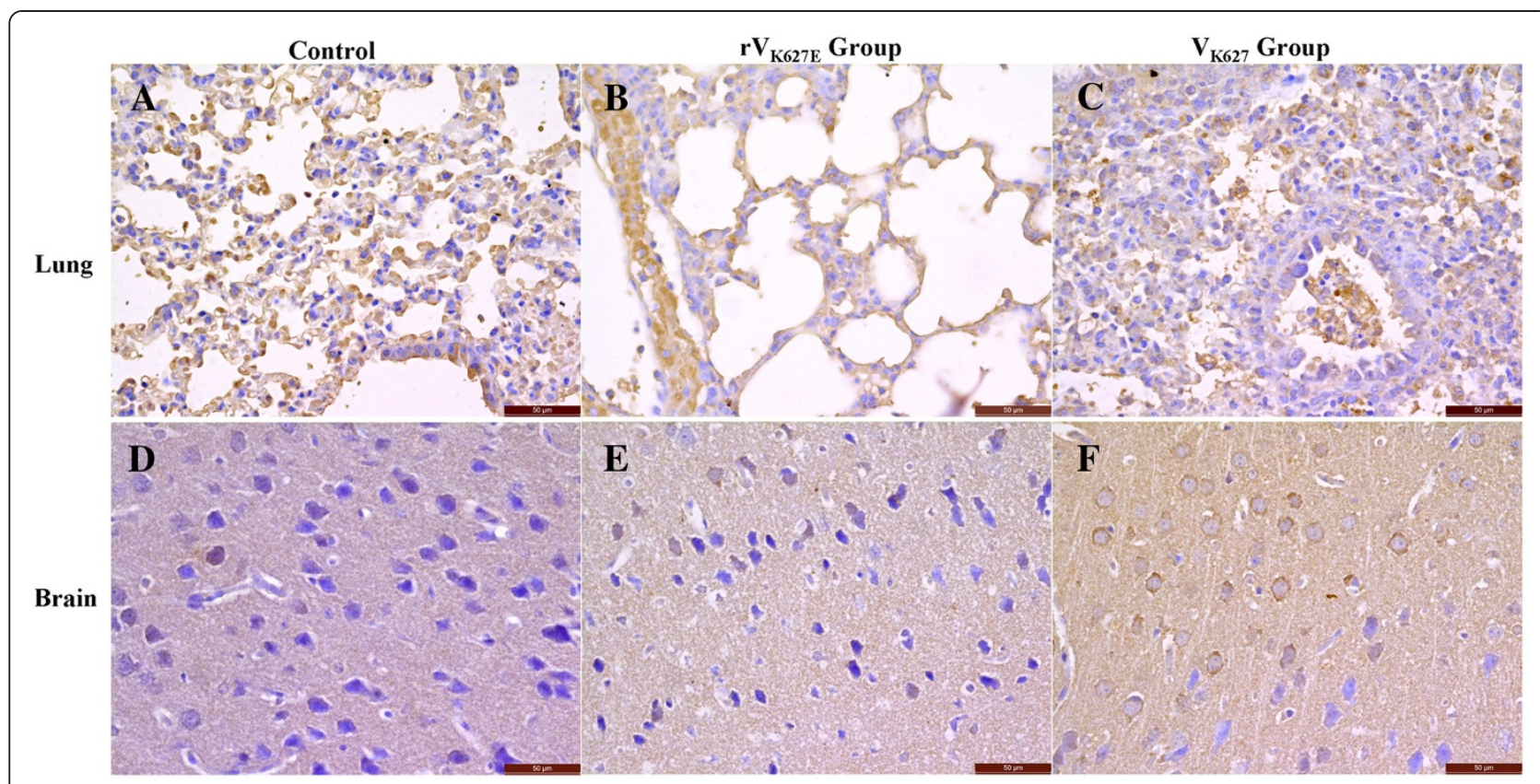

Figure 2 Distribution of NLRP3 in the lung and brain of infected BALB/c mice and the control at $\mathbf{5}$ dpi. Scale bar $=50 \mu \mathrm{m}$. A, B and C: Lung of control, $r V_{\text {K627E }}$ and $V_{K 627}$ group, respectively; $\mathbf{D}, \mathbf{E}$ and $\mathbf{F}$ : Brain of control, $r V_{\text {K627E }}$ and $V_{\text {K627 }}$ group, respectively.

The data of expression level of NLRP3, IL-1 $\beta$ and TNF- $\alpha$ in lung showed that they were changed by H9N2 avian influenza virus infection. In infected groups, the expression level of NLRP3, IL-1 $\beta$ and TNF- $\alpha$ increased rapidly at $3 \mathrm{dpi}$ and $\mathrm{V}_{\mathrm{K} 627}$ infection were higher than that of $\mathrm{rV}_{\mathrm{K} 627 \mathrm{E}}$. These data implied that NLRP3 inflammasome and its signal pathway in lungs had been activated by H9N2 AIV infection and the site 627 contributed to these changes. The histopathological changes of the lung also proved this. In the brain, the expression level of NLRP3 and IL-1 $\beta$ in $V_{K 627}$ group increased rapidly while $\mathrm{rV}_{\mathrm{K} 627 \mathrm{E}}$ infection not, this suggested that $\mathrm{V}_{\mathrm{K} 627}$ infection can activate the inflammatory processes of brain quickly while $\mathrm{rV}_{\mathrm{K} 627 \mathrm{E}}$ infection can not. Meanwhile, the anti-virus replication function cytokine TNF- $\alpha$ of $\mathrm{rV}_{\mathrm{K} 627 \mathrm{E}}$ groups are significant higher than the other two groups. Interestingly, expression level of TNF- $\alpha$ declined in lung while increased in brain at 6 dpi after infection. These information may explain that why the viral encephalitis only in $V_{K 627}$ infection while $r V_{K 627 E}$ not.

Results of immunohistochemical detection showed that NLRP3, IL-1 $\beta$ and TNF- $\alpha$ were constitutively expressed in lungs and brains of $B A L B / c$ mice. When the H9N2 avian influenza virus infection occurred in

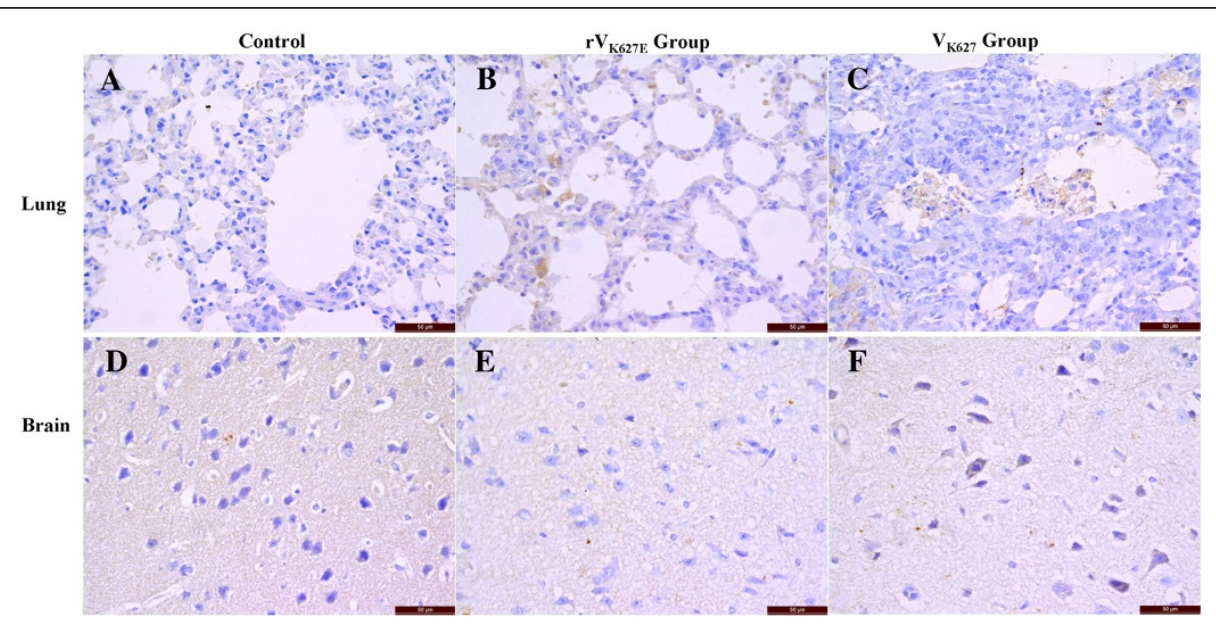

Figure 3 Distribution of IL-1 $\boldsymbol{\beta}$ in the lung and brain of infected BALB/c mice and the control at $\mathbf{5}$ dpi. Scale bar $=50 \mu \mathrm{m}$. A, B and C: Lung of control, $\mathrm{V}_{\mathrm{K} 627 \mathrm{E}}$ and $\mathrm{V}_{\mathrm{K} 627}$ group, respectively; $\mathbf{D}, \mathbf{E}$ and $\mathbf{F}$ : Brain of control, $\mathrm{V}_{\mathrm{K} 627 \mathrm{E}}$ and $\mathrm{V}_{\mathrm{K} 627}$ group, respectively. 


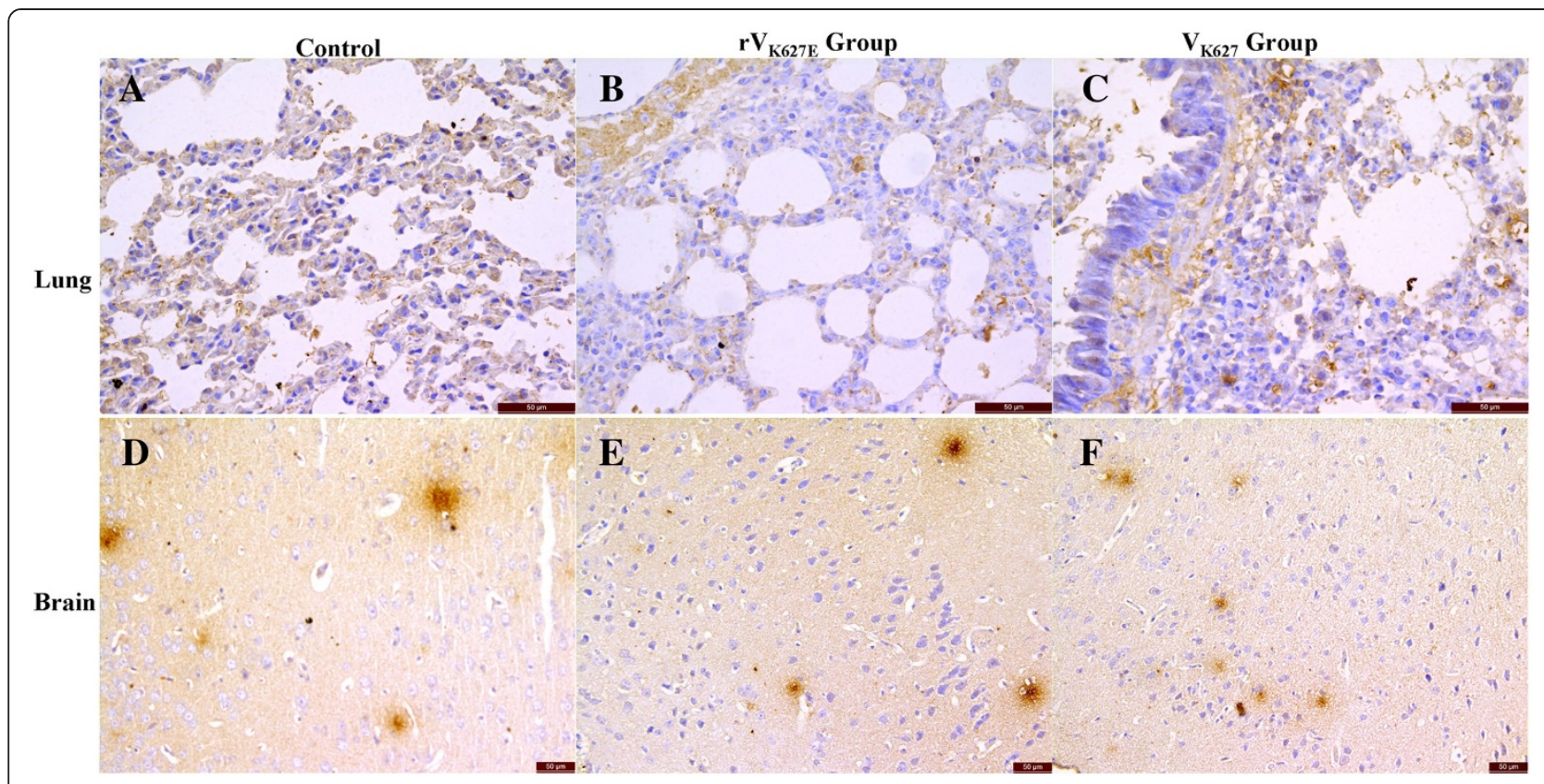

Figure 4 Distribution of TNF- $\boldsymbol{a}$ in the lung and brain of infected BALB/c mice and the control at $\mathbf{5} \mathbf{d p i}$. Scale bar $=50 \mu \mathrm{m}$. A, B and C Lung of control, $V_{\text {K627E }}$ and $V_{K 627}$ group, respectively; D, E and $\mathbf{F}$ : Brain of control, $V_{\text {K627E }}$ and $V_{K 627}$ group, respectively.

$\mathrm{BALB} / \mathrm{c}$ mice, there were changes in quantity. The exudates cells and liquid in lung showed positive indicate that NLRP3, IL-1 $\beta$ and TNF- $\alpha$ exist in this inflammation infiltration. To our knowledge, there are very few papers which give the tissue distribution of NLRP3, IL-1 $\beta$ and TNF- $\alpha$ for normal and influenza virus infected BALB/c mice. The cell and tissue-specific distribution of NLRP3, IL-1 $\beta$ and TNF- $\alpha$ in the BALB/c mice will help to elucidate the role of victim tissues in AIV infection.

\section{Conclusion}

In conclusion, our data showing the expression patterns of NLRP3, IL-1 $\beta$ and TNF- $\alpha$ in H9N2 AIV infected mice further support that NLRP3 inflammasome protein play a crucial role in the physiological and pathological processes of influenza infection. Both $\mathrm{V}_{\mathrm{K} 627}$ and $\mathrm{rV}_{\mathrm{K} 627 \mathrm{E}}$ infection can active the expression of NLRP3, IL-1 $\beta$ and TNF- $\alpha$ in the lung and brain of BALB/c mice at different levels and this also improved that site 627 in PB2 takes part in the virulence of H9N2. This basic data will enhance our understanding of the inflammatory process during influenza and develop the new strategies to antiinfluenza based on the NLRP3.

\section{Materials and methods}

Viruses and $B A L B / C$ mice infection by $\mathrm{H} 9 \mathrm{~N} 2$ influenza virus H9N2 AIV viruses used in study were A/chicken/Guangdong/ $\mathrm{V} / 2008\left(\mathrm{~V}_{\mathrm{K} 627}\right)$ and a site-mutation virus $\left(\mathrm{rV}_{\mathrm{K} 627 \mathrm{E}}\right)$ which was rescued by eight-plasmid reverse genetic system [21,22]. Thirty-six SPF female BALB/c mice (18.0-
20.0 g, 6 weeks) from Guangdong Experimental Animal Centre, Guangzhou, China were used in this research and randomly divided into two infection and control groups. The procedures and steps of management and challenge test by this two H9N2 AIVs strains are similar to our previous reports $[21,22,31]$. The animal experiments were approved by the Institutional Animal Care and Use Committee at the South China Agricultural University (Certification Number: CNAS BL0011).

\section{Tissue preparation}

Lungs and brains of three mice in each group were collected promptly at 1, 3, 5 and $6 \mathrm{dpi}$. Each tissue was divided into two parts, one for total RNA extraction and the other for histopathological and immunohistochemistry detection.

\section{RNA extraction, cDNA preparation and quantitative real-time PCR}

The procedures and steps of total RNA, cDNA preparation and quantitative real-time PCR were similar to our previous reports $[21,22,28,31]$. Relative expression levels of NLRP3, IL-1 $\beta$, and TNF- $\alpha$ using the $2^{-\triangle \Delta C t}$ formula and endogenous housekeeping gene $\beta$-actin for normalizing. The primer sequences were synthesized as follows: 5' - ACCAGCCAGAGTGGAATGA -3'(NLRP3-Fw), 5'- GCGTGTAGCGACTGTTGAG -3(NLRP3- Rv), 5'CTCGTGCTGTCGGACCCAT -3'(IL-1 $\beta$-Fw), 5' - CAGGC TTGTGCTCTGCTTGTGA -3'(IL-1 $\beta$ - Rv), 5'-TCTCATTC CTGCTTGTGGC -3'(TNF- $\alpha-F w), 5$ ' - CACTTGGTGGTT 
TGCTACG-3' (TNF- $\alpha-R v), 5^{\prime}$-CATCCGTAA AGACCTCTA TGCCA-3' $\left(\beta\right.$-actin-Fw) and $5^{\prime}$ - ATGGAGCCACCGATCC ACA-3' $(\beta$-actin-Fw). Statistical analysis of the data was performed by using $t$ test and one way anove using GraphPad Prism 5 (GraphPad Software, La Jolla, CA). Data are expressed as the mean \pm SD from three separate experiments.

\section{Histopathological and immunohistochemical detection}

The procedures and steps of tissue section preparation were similar to our previous reports $[28,31]$. Serial sections were taken from the same sample, one for histopathological observation by H.E. staining and the other for immunohistochemical detection. After the endogenous peroxidase activity was quenched, antigen retrieval was performed and necessary washed, the slices then incubated with correspondence antibodies (antibody for NLRP3, abcam, Cat.No., ab4207; antibody for IL-1 $\beta$, santa crus biotechnology, sc-7884; antibody for TNF- $\alpha$, abcam, Cat.No., ab6671), diluted 1:200 for antibodies of NLRP3 and TNF- $\alpha$ and 1:150 for antibody of IL-1 $\beta$, for $2 \mathrm{~h}$ at $37^{\circ} \mathrm{C}$. After incubation with the correspondent secondary antibody for $1 \mathrm{~h}$ at $37^{\circ} \mathrm{C}$, the slices were washed 3 times by PBS at 5 minutes intervals. Then used DAB (3, 3 -diaminobenzidine -tetrahydrochloride) kit for coloration and re-dyed with hematoxylin.

\section{Competing interests}

The authors declare that they have no competing interests.

\section{Authors' contributions}

Conceived and designed the experiments: WQ, ML and ZN. Performed the experiments: MY, KZ, ZH, WQ and JY. Analyzed the data: MY, KZ, ZH, WQ,JY, and YM. Wrote the paper: MY, KZ, WQ and ZN. All authors read and approved the final manuscript.

\section{Acknowledgements}

This work was partially supported by Science \& technology nova Program of Pearl River of Guangzhou (2014), Development Program for Excellent Young Teachers in Guangdong Province (2013), Program for National Broiler Industry (nycytX-42-G3-03) and Natural Science Foundation of Guangdong Province (\$2013010013041).

Received: 30 July 2014 Accepted: 16 December 2014

Published online: 30 December 2014

\section{References}

1. Kawaoka Y, Chambers TM, Sladen WL, Webster RG: Is the gene pool of influenza viruses in shorebirds and gulls different from that in wild ducks? Virology 1988, 163:247-250.

2. Alexander DJ: A review of avian influenza in different bird species. Vet Microbiol 2000, 74:3-13.

3. Arafa AS, Hagag NM, Yehia N, Zanaty AM, Naguib MM, Nasef SA: Effect of cocirculation of highly pathogenic avian influenza $\mathrm{H} 5 \mathrm{~N} 1$ subtype with low pathogenic H9N2 subtype on the spread of infections. Avian Dis 2012, 56:849-857.

4. Davidson I, Shkoda I, Golender N, Perk S, Lapin K, Khinich Y, Panshin A: Genetic characterization of HA gene of low pathogenic H9N2 influenza viruses isolated in Israel during 2006-2012 periods. Virus Genes 2013, 46:255-263.

5. Zhang K, Zhang Z, Yu Z, Li L, Cheng K, Wang T, Huang G, Yang S, Zhao Y, Feng N, Fu J, Qin C, Gao Y, Xia X: Domestic cats and dogs are susceptible to H9N2 avian influenza virus. Virus Res 2013, 175:52-57.
6. Sun X, Xu X, Liu Q, Liang D, Li C, He Q, Jiang J, Cui Y, Li J, Zheng L, Guo J, Xiong $Y$, Yan J: Evidence of avian-like H9N2 influenza A virus among dogs in Guangxi, China. Infect Genet Evol 2013, 20:471-475.

7. Yu H, Zhou YJ, Li GX, Ma JH, Yan LP, Wang B, Yang FR, Huang M, Tong GZ: Genetic diversity of H9N2 influenza viruses from pigs in China: a potential threat to human health? Vet Microbiol 2011, 149:254-261.

8. Perez DR, Lim W, Seiler JP, Yi G, Peiris M, Shortridge KF, Webster RG: Role of quail in the interspecies transmission of $\mathrm{H} 9$ influenza $\mathrm{A}$ viruses: molecular changes on HA that correspond to adaptation from ducks to chickens. J Virol 2003, 77:3148-3156.

9. Govorkova EA, Rehg JE, Krauss S, Yen HL, Guan Y, Peiris M, Nguyen TD, Hanh TH, Puthavathana P, Long HT, Buranathai C, Lim W, Webster RG, Hoffmann E: Lethality to ferrets of $\mathrm{H} 5 \mathrm{~N} 1$ influenza viruses isolated from humans and poultry in 2004. J Virol 2005, 79:2191-2198.

10. Guo YJ, Krauss S, Senne DA, Mo IP, Lo KS, Xiong XP, Norwood M, Shortridge KF, Webster RG, Guan Y: Characterization of the pathogenicity of members of the newly established H9N2 influenza virus lineages in Asia. Virology 2000, 267:279-288.

11. Kim JA, Cho SH, Kim HS, Seo SH: H9N2 influenza viruses isolated from poultry in Korean live bird markets continuously evolve and cause the severe clinical signs in layers. Vet Microbiol 2006, 118:169-176.

12. Coman A, Maftei DN, Krueger WS, Heil GL, Friary JA, Chereches RM, Sirlincan E, Bria P, Dragnea C, Kasler I, Gray GC: Serological evidence for avian H9N2 influenza virus infections among Romanian agriculture workers. I Infect Public Health 2013, 6:438-447.

13. Huang $R$, Wang AR, Liu ZH, Liang W, Li XX, Tang YJ, Miao ZM, Chai TJ: Seroprevalence of avian influenza H9N2 among poultry workers in Shandong Province, China. Eur J Clin Microbiol Infect Dis 2013, 32:1347-1351.

14. Lam TT, Wang J, Shen Y, Zhou B, Duan L, Cheung CL, Ma C, Lycett SJ, Leung CY, Chen X, Li L, Hong W, Chai Y, Zhou L, Liang H, Ou Z, Liu Y, Faroogui A, Kelvin DJ, Poon LL, Smith DK, Pybus OG, Leung GM, Shu Y, Webster RG, Webby RJ, Peiris JS, Rambaut A, Zhu H, Guan Y: The genesis and source of the H7N9 influenza viruses causing human infections in China. Nature 2013, 502:241-244.

15. Liu D, Shi W, Shi Y, Wang D, Xiao H, Li W, Bi Y, Wu Y, Li X, Yan J, Liu W, Zhao G, Yang W, Wang Y, Ma J, Shu Y, Lei F, Gao GF: Origin and diversity of novel avian influenza $A H 7 N$ 9 viruses causing human infection: phylogenetic, structural, and coalescent analyses. Lancet 2013, 381:1926-1932.

16. Chen $H$, Yuan $H$, Gao R, Zhang J, Wang D, Xiong Y, Fan G, Yang F, Li X, Zhou J, Zou S, Yang L, Chen T, Dong L, Bo H, Zhao X, Zhang Y, Lan Y, Bai T, Dong J, Li Q, Wang S, Zhang Y, Li H, Gong T, Shi Y, Ni X, Li J, Zhou J, Fan J, et al: Clinical and epidemiological characteristics of a fatal case of avian influenza A H10N8 virus infection: a descriptive study. Lancet 2014, 383:714-721.

17. Monne I, Yamage M, Dauphin G, Claes F, Ahmed G, Giasuddin M, Salviato A, Ormelli S, Bonfante F, Schivo A, Cattoli G: Reassortant avian influenza A (H5N1) viruses with H9N2-PB1 gene in poultry, Bangladesh. Emerg Infect Dis 2013, 19:1630-1634.

18. Munir M, Zohari S, Iqbal M, Abbas M, Perez DR, Berg M: The non-structural (NS) gene segment of H9N2 influenza virus isolated from backyard poultry in Pakistan reveals strong genetic and functional similarities to the NS gene of highly pathogenic H5N1. Virulence 2013, 4:612-623.

19. Yu X, Jin T, Cui Y, Pu X, Li J, Xu J, Liu G, Jia H, Liu D, Song S, Yu Y, Xie L, Huang R, Ding H, Kou Y, Zhou Y, Wang Y, Xu X, Yin Y, Wang J, Guo C, Yang $X$, Hu L, Wu X, Wang H, Liu J, Zhao G, Zhou J, Pan J, Gao GF, et al: Influenza H7N9 and H9N2 viruses: coexistence in poultry linked to human H7N9 infection and genome characteristics. J Virol 2014, 88:3423-3431.

20. Choi YK, Ozaki H, Webby RJ, Webster RG, Peiris JS, Poon L, Butt C, Leung YH, Guan Y: Continuing evolution of H9N2 influenza viruses in Southeastern China. J Virol 2004, 78:8609-8614.

21. Tian J, Qi W, Li X, He J, Jiao P, Zhang C, Liu GQ, Liao M: A single E627K mutation in the PB2 protein of H9N2 avian influenza virus increases virulence by inducing higher glucocorticoids (GCs) level. PLoS One 2012, 7:e38233.

22. Li X, Qi W, He J, Ning Z, Hu Y, Tian J, Jiao P, Xu C, Chen J, Richt J, Ma W, Liao M: Molecular basis of efficient replication and pathogenicity of H9N2 avian influenza viruses in mice. PLoS One 2012, 7:e40118.

23. Martinon F: Detection of immune danger signals by NALP3. J Leukoc Biol 2008, 83:507-511.

24. Zhang C, Boini KM, Xia M, Abais JM, Li X, Liu Q, Li PL: Activation of Nodlike receptor protein 3 inflammasomes turns on podocyte injury and 
glomerular sclerosis in hyperhomocysteinemia. Hypertension 2012, 60:154-162.

25. Halle A, Hornung V, Petzold GC, Stewart CR, Monks BG, Reinheckel T, Fitzgerald KA, Latz E, Moore KJ, Golenbock DT: The NALP3 inflammasome is involved in the innate immune response to amyloid-beta. Nat Immunol 2008, 9:857-865.

26. Zhang N, Zhang X, Liu X, Wang H, Xue J, Yu J, Kang N, Wang X: Chrysophanol inhibits NALP3 inflammasome activation and ameliorates cerebral ischemia/reperfusion in mice. Mediators Inflamm 2014, 2014:370530.

27. Zhao G, Liu C, Kou Z, Gao T, Pan T, Wu X, Yu H, Guo Y, Zeng Y, Du L, Jiang $S$, Sun $S$, Zhou Y: Differences in the pathogenicity and inflammatory responses induced by avian influenza A/H7N9 virus infection in BALB/C and C57BL/6 mouse models. PLoS One 2014, 9:e92987.

28. Huang Z, Yu M, Tong S, Jia K, Liu R, Wang H, Li S, Ning Z: Tissue-specific expression of the NOD-like receptor protein 3 in BALB/c mice. J Vet Sci 2014, 15:173-177.

29. Lin TY, Brass AL: Host genetic determinants of influenza pathogenicity. Curr Opin Virol 2013, 3:531-536.

30. Otte A, Sauter M, Alleva L, Baumgarte S, Klingel K, Gabriel G: Differential host determinants contribute to the pathogenesis of 2009 pandemic H1N1 and human H5N1 influenza A viruses in experimental mouse models. Am J Pathol 2011, 179:230-239.

31. Tong S, Tian J, Wang H, Huang Z, Yu M, Sun L, Liu R, Liao M, Ning Z: H9N2 avian influenza infection altered expression pattern of sphiogosine-1phosphate receptor 1 in BALB/c mice. Virol J 2013, 10:296.

\section{Submit your next manuscript to BioMed Central and take full advantage of:}

- Convenient online submission

- Thorough peer review

- No space constraints or color figure charges

- Immediate publication on acceptance

- Inclusion in PubMed, CAS, Scopus and Google Scholar

- Research which is freely available for redistribution 